\title{
マヌエル・ロハス作『南部の人々』 に現われるチリー人
}

吉田秀太 郎

序

作者 Manuel Rajas は，現代チリ一文壇を代表するには至らないまでる，その連峰 の一端に, つつましやか乍らも独自の姿を見せている。彼は1890年，フルゼンチンの首 都ブェノス・アイレスに生まれた。チリー人を両親に持つ彼の生活は決して楽なるので はなかった。家事の手倊などで忙しく，学校へは，行こうにも行けなかった。1926年 に祖国チリーに帰ってきたが，それまでに転々と職業を変えていった。それる，道路工 夫だとか，波止場の人足だとか，植字工など，大ていは肉体労働の場合が多かった。そ らした苦しい生活環境にありながらも, 彼は自分の好きな文学への精進を怠らず，自か らの手で, その開拓にいそしんだ。そして, 現在も, チリー大学出版局に勤務のかたわ ら，その文筆活動を続けている。

さて，彼の作品に注目してみると，主なものとしては，Hombres del sur (1927年), Lonchas en la bahía (1932年), El bonete maulino (1943), Hijo de ladrón (1951) がある。更にこれらの短編小説の他に彼は Tonada del transeunte などの詩集も出し ている。

以上の, 簡単な紹介によってもかかる様に, Hombres del sur は, 彼の, 比較的初 期の作品である。

サンチャゴの出版社 Zig-Zag，から「チリー作品文庫」の一部として出されれたこの短 編集は, Laguna, Un espíritu inquieto, El cachorro, El bonete maulino, El homre de los ojos azules の五編から成り立っており，特に，年代的に見て相当開きのある El bonete maulino が収められているのが変っている。題名の「南部の人々」とは, チリーの南部に住む人々のことで，作者の生活と深い関係のある，土着民の生活を描い たものた。先に述べた個々の小品の題名からは一見何ら共通したものは見られ奴様だが 
実察には，これからすかかる通り，夫々の作品の間に互に一脈相通ずるすのがある。結 論を先に言 5なら，これらの作品を通じて，作者は，本当にチリー人らしいチリー人の 姿をとらえようとしている。それたけに我々にとっては，彼らの心の奥底に流れる民族 の血潮を感じとる意味で, 興味のあるすのだ。今, 順を追って夫ょの作品に目を通して ゆくと，先ず Laguna である。

\section{Laguna——宿命的な男}

Laguna は, 物語りに現われる主人公の名で, それが彼の本名なのか, 渾名なのか判 然としない。何れにせよ，彼は生粋のチリー人で，フラウカ族の直系であり，彼自身， そうであることを誇りとしている。(Soy chileno; de Santiago. Pura araucanía)。こ の人物の悲劇的な生涯を, 同僚であり, 後には親友となった同じチリーの一青年が描い てゆく。二人とも，失業からやっと解放されて，アルゼンチンとチリーを結ぶアンデス 横断鉄道に，線路工夫として働けるよ5になった，いわゆる人生の底辺を歩む男た。。酷 寒の僻地に働らく彼等の生活には, 運命の女神は䅡笑まず, 彼等自身の不屈の精神と勇 敢さのみが唯一の頼みなのだ。Laguna は, テントの中で, 五人の労務者に対して一枚 しか支給されていない毛布を敢えて同僚に譲り，自分は，作業着のまま地べたに寝ころ ふ。そして翌日再び雪除け作業に出る。彼は，与えられた運命に対し，敢えて逆らお としない。不幸が寸時でも途切れるのをいぶかるかの如く, 又自から不幸を求めている かの様であった。深い積雪の中を歩むとさにも，彼は必らず同僚の先頭に立っていた。 枕木を運ぶ作業は苦しかった。倲死の瀬戸際に追いやられたことも幾度かあったが，彼 は，その許に，甘い夢でも見ているかの様に，笑みを浮かへていた。そして彼の遭遇す る苦難の数々も, 遂にチメートルの谷底の彼方に, 雪崩と共に消え去る彼の五体と共に 終りをつげる。

人里離れたアンデスの峰遠く，大自然の猛威と戦いながら働らく人々の苦しみと，そ こに咲く美しい友情の花, そして, 黙々として自己の運命に甘んじ, 遂には悲劇的な生 涯を閉じる Laguna の生き方，これは，とりもなおさず，チリー人の国民性の重要な 部分を占めているのだと言って，決して過言ではない。チリー人，生えぬきのチリー人 の性格は，まさにこの作者の筆によって，巧みに描き出されている。

作者自身が，この小説の中で，Laguna の友人に言わせている様に，チリー人は，特 
に労働者の中では根気強く, 努力家であるので有名だ。そして又, 運命に対するストイ ックな態度も彼らに共通のものた。察するに, これらの特質は, アラウカ族の気性その ものた。その昔, インカ帝国の権勢隆々たりし頃, チリーに向かってその勢力を南下世 しめようとして，アラウカ族の果敢な反抗に会い，遂にその目的を達成することが出来 なかったことがあった。更に，イスパニア人がはじめてこの土地に足を踏み入れたとき にも，彼ら土着民の勇敢さか，遺憾なく発揮されたことは，かの有名な叙事詩 La ara・ ucana にも明らかに見られるところだ。そうした民族的特質が，イスパニア人との混血 によっても，些かも損なわれることがなかったっこうした，チリー人の特質は，彼らの 日常生活に於いて, 絶えず観察されるところである。Laguna が, 雪の中で涷死しかか っているのを見つけた同僚が，彼の体を抗こし，ポンチョや上衣でたたきつけ，活を入 れたとき，ハッと我にかえり，一－Ｙａ está bueno！iYa está bueno！と叫びながらは ね起き，手足の運動をしながら，
Suspirando te llamé
あんなに呼んだに
y a mi llamado no vienes
来てくれぬ
como me ves sin trabajo
仕事のない俺いやなのか
te haces sorda y no me entiendes
聞えないふり，知らぬ顔。

と, 小唄をロにしながら, 又もドーと地上に倒れる条は, 我々に, 彼の強烈な精神力を 余すところなく見せてくれる。しかし，そこには又，一つのあきらめにも似たものがあ ることは見逃がせない。彼は, 自分の身にふりかかっている不幸を語るのに, 半ば自潮 的な笑い声を混えている。どうせ，自分は，これたけの者なのた，これ以上はどににる ならないのだと言っている様た。この様にして, 作者は, この作品の随所に, 彼の宿命 論者的な人生観をその主人公に託して，浮き彫りにしている。Laguna は言っている。 -Yo soy roto muy fatal, hermano. (p. 10.) と。同じ文句は他の籄所にも見られるし, 同時に作者自身，その叙述文の中で, iPobre Laguna! Verdaderamente, era fatal と 言ったり, 更に fatalidad と言 弓名詞を頻繁に用いているのは, 作者が，彼の同国人に 対して抱いている，そして彼自身もその一人なのたが，偽らざ心の告白であろ5。彼 らの宿命論者的な人生観も, 元を正せば, やはり, 彼等の民族的な性格と, その歴史的 16 
社会的背景にあると考えられる。これは，ひとりチリー人にのみあり得ると言うもので はなく，一般に被征服民族には，個有のものた。何百年にわたる従属的地位は，彼らを して，少なからず卑屈にしてきた。その精神的な流れは，今日立派な独立国となっても 尚, 完全に払侙することは出来ない程, 根強いのもになっているのだ。

Laguna に見られる無常感, 宿命論。人生のはかなさを知りつつも, 尚生き抜こ 5 と する生への執着と, 同時に Laguna をしてその様な人生を送らしめている社会的, 文 化的条件に対する作者の激しい批判精神とがにじみ出ている作品と言えるだろう。こう した作者の態度は, この短編集の他の簓所にも伺がえる。これは多分に, 彼の生い立ち に，彼が自から味わってきた苦しい生活体験から生まれたものであると考える。

\section{Un espíritu inquieto一一迷える男}

ヨブの言葉を借りるまでもなく, 女から生まれ, 命短かく, 苦しみ多く, 草花の様に 現われては摘みとられ，影の様に去っては滞まることのないのが人間である。ここに現 われる主人公 Pablo González む, やはり人の子。しかむ, 恵まれない生活環境にあっ て，その人生の苦しみには，一しお深いものがあった。家族も，親威もなくただ一人， その上, 目下失業中とあっては, 人間, これ程淋しいことはないだろう。しかし, 同時 に, 別の角度から見れば, この世に一人たけと言う状態は, 作者も言っている様に（EI hombre que está solo es el más fuerte). かえってその人間に力を与えるものかる知 れない。人間は，特に若い時には大きな希望と小さな思い出で生きているすのだ。そし てその希望は，その形や種類に差はあっても，どんなに困難な瞬間においても心の奥梁 く抱いている。Pablo Gonzálz にしても同じだった。しかしながら，紙に表裏のある様 に希望を裏返せば，そこには言い尽せない不安があった。そして，希望が大きければ大 きいほど, 不安す增大する, 彼は, 人間の死と, 霊魂の行くえに対する疑惑のとりこと なってしま5。Vocilante en su espíritu，これこそ主人公の内的な姿を最も的確に表わ している言葉である。では, 何故, 主人公はこの様な問題に興味と関心を摭えたので あろらか? それは, 彼の环独な, 社会から見放された状態に, その船答を求めらるへ きであろ5。

このストーリーで, 主人公 Pablo González は, 交通事故で死亡する。しかし自分に は, その意味がわからない。自分が死亡していると気がつくのは, しばらく経って, 或 
る旧友に (勿論死亡しているが) 教えられてからのことだった。それを知ったときの彼 の言葉, De buena me he librado は, その意味するところ, 深長と言わねばなるま い。死によって, 彼は, 現世の苦しみから解脱出来ると考えたのた。この世を去ること が，とりもな持さず自由の身となることだと考えたに違いない。しかし，そこに待ち受 けていたものは, 必らずしも楽園ではなかった。勿論, 死後の世界は誰も見たことがな いのだから，飽くまで作者の想像に過ぎないけれども，そこに又，彼の持つ人生観，世 界観が伺がえると言う点で興味深いものがある。

偖, Pablo González の見た死後の世界はどんなものであったろらか? 生前, 彼に は, 死後の世界が，何か超自然的なものに思われていたのに，今肉体的に死亡してみる と，そして新しい世界に入ってみると，今までと何一つ変っていないのに気つく。つま り，肉体は亡びても，魂は存続する。だからこそ，彼が，君は死んでいるのたと友人に 知らされたとき嬉しかったのと同時に心残りのしたものは, 死の直前に着ていた青いオ ーバーコートだったのだ: 主人公の塊は自由自在に, 何処へでも行けるが, 決して人間 に見つからない。彼と友人 Alfredo Valenzuela との二つの魂の対話は我々の注意をひ く。死とは何かとの質問に答えてその友人は,「死とは肉体と精神との分離現象に他な らない。正確には，肉体即ち物質も完全に消隇してしまうのではなくて，たた異質のも のとなるだけた。従って, 無くなるのは, 社会的動物としての人間だけなのた」と大略 その様に言っている。更に言葉を続けて, 魂は, 丁度, 片足を切断した男が, 二三日経 ってから今はない足を撜こ 5 とする様に, 死後も, 生前の人間にあったときの習慣から 容易に抜けきれないと言っている。Valenzuela に託した作者の想像が正しいか否かは 別として，面白い見方ではある。肉体から分離した魂から見た人間社会の諷刺も，この 作品の中で, 作者の意図したものの重要な一部であろう。たとえば，神様がのり移った とか言ってさわいでいる神霊術者の姿などがそれである。

偖, 魂は, 惰性によって, 生前のそれを継承することに基き, 生前なやめる魂は死後 る尚, 安住の地を得ないままに, なやみ, さまよい続ける。こうした Pablo González に対して, Pero, querido Pablo, me pareces un espíritu inquieto en demasía, y esto te será fatal. と友人はなだめるが，彼の悲しみは，一向に減らないのだ。精神的な面 では何一つかなえられないものはないのに, 尚, 彼は悲しい。Yo estoy triste…と彼は 言う。それは何故か？ 彼は完全な亡霊となるよりる, 完全な人間でありたいと望んで 
いるからに他ならない。彼は生前, 充分に有意義な人生をエンジョイ出来なかったこと を後海している。そこで，今は，少なく，とも生きている人間たちに，有意義に生きよと 教えたい。しかしそれは魂だけとなっている彼には出来ない。死亡してみてはじめて人 間には，それがわかるのだ。そこに，彼の言５人間の fatalidad があり，弱さがある。 死後る尚救われない魂の世界から脱出する方法は只一つしかない。それは, 魄よりも更 に高度なるのへの界華である。氷遠にさまよう espiritu inquieta となるに耐えかねて， 遂に彼は水に生まれ代万弓とする。川岸に立って, やがて人間がする様に, 水中に飛ひ 込む。しかし，誰もそれに気がつかず，助けに来てくれない。

主人公 Pablo González の魂は，過去の悲しい人生に一種の悔恨を感し，且つ或る， スタルジーにも似たものを禁じ得ないまま，永遠のさまよいに終止符を打って水と化し てしまうが，これは，測り知れ姓命の神秘に，敢えて立ち向かった作者の，当然行き つくところであって, 所詮は神なら㴬の如何ともし難いものである。作者の, 悲観論 者的な性格がにじみ出ている。暗い作品であって, 前の作品同様, 彼の思想の根幹をな している。

\section{El cachorro—チリー人の憧憬—}

さきの', Espíritu inquieto は，主人公はチリー人ではあったが，南部の人々とは直 接関係はなかった。それにひきかえ,この $\mathrm{El}$ cachorroは Laguna 同様, チリー, ア ルゼンチンを結ぶンデス横断鉄道を舞台としている。題名の cachorro とは，仔犬と か，虎の子の様に一般に猛獣の子どすの意味で, ここでは主人公 Vicente の別名であ る。この点でも Laguna と似ている。話の筋は, 上記の鉄道工夫である Vicente が, 今はなき父親の勇名と，その痛ましい死を忘れることが出来ず，歎難辛苦の末，遂に父 の仇を打つと言 5話である。些か時代錯誤的なストーリーではあるが, 今もって,この 地には見られる風景である。作者は, 主人公 Vicente に, チリー人の, 生粋のチリー 人の心の英雄とも言うべき，男性の理想像を見ている。女性らしい女性に蛙力がある様 に，男性らしい男性は誰しも望むところであろう。たた，その表現の方法が，時代によ っで, 又地域によって違らだけである。問題をチリー人に充てはめると, 生粋のチリー 人は，中央部の温暖な地方を除いて，絶え間ない大自然との戦の中に生きている。そし て常に大いなる勇気と，決断力を迫られている。そうした自然環境から，幾世代にわた 
って培われてきた彼らの精神に加えて，民族的な特質に由来する勇敢さは，チリー人の 共通して持つるのであり, 更にそうした環境にあって習得した協調の精神，暖かい人情 味も見逃がすことが出来ない。それは一見, 一食一飯の恩義を忘れぬやくさの世界の様 な, 浪曲の世界の様な観がある。その点に於て如何にも東洋的な性格が目立っている。 作者は，さきに Laguna においてもこうした性格をその主人公に持たせているところ から,こうしたテーマ乃至は楎想は, 彼の最も得意とするものの様である。

IV. El boneto maulino—— サー人の鄉愁——

これは，マウラ帽（麦わら帽で縁が上方に巻き上がっている）にまつわるエピソード であって, チリー中南部の田舎の生活と; 古きよき時代への郷愁を感じさせている。叙 述の構想は, 或る男が, チリーはタルカ州, マウレの町のある店で偶然, 件の帽子を見つ け，それを主人が売りたくないと言うのを無理にたのんで家に持ち帰ると，彼の母が， その帽子はこの町で昔有名だった Leiva のではないかと言5。そしてそこから Bonete の話となるわけである。偖，さっきの帽子の件たが，何故その店の主人が売りたがらな かったかの理由の大略はこうである。

Bonete と渾名された一人の工夫がふとした事から同僚を殺し，整察に追われて，タ ルカの山野をさまよっていた。彼を知っている町の人々は何か事ある毎にそれを彼のせ いにしたので，重い罪をきせられるのを恐れてなかなか自首しない。追いつめられた彼 が，たまたまこの店に立奇ったのを，店の主人がかくまってやろうと申し出るが，迷惑 をおかけしては，とことわり，帽子をかむる叞もなく馬をとばして消え去る。すぐ後を 整察が追うが, やがて銃声のあと, 帰ってきたのは, Bonete とその整官の二つの死体 だった。

こんな訳で，店の主人には，Bonete が不粼でならなかったのだった。

偖, 話を本筋である Leiva のことに戻そ5。Leiva は, 典型的なチリー人である。 ユーモアに富んでいて, 勇敢で, 敵, 味方の意識が強く, 飽くまでお人好しで, 献身的 である。只, 付属的な事項として，ここでは彼が人殺しをしているために特別な状況に おかれているが，それは，偶発的なことであって何ら基本的な重要性をもっていない。

彼は若い時，両親に首都，サンチャゴへやられ，そこで僧院の雇人となるが，元来， こう言う仕事には向かない性質の彼は, そこを逃げ出て Talca の町へ行き, 鞉屋をは 
じめる。愉快な性格は到るところで人々に歓迎され; 何かと目出度い席には必らずと言 ってよい程，招ねかれる，が決してそれを商売にしている訳ではない。こうしたタイプ の人間は, チリーの田舎に，よく見かけられるものである。彼等は大てい小話などを十 か二十は用意していて，事ある毎にそれらを披露し;。居合わせる人々はそれを聞いて或 いは微笑し，或いは腹をかかえて笑いこける。

さて，結婚して，人間的にも成長した彼は，仕事に熱を入れる。妻の Angela は， つつましやかな女性だった。甘く，優しく，濡れた様な瞳の持ら主で，かいがいしく家 事にはげんだ。彼は満足していた。しかし或る日，彼は初老の訪ずれを感じるこれま での，水々しい果物の様な人生は，やがて，時間と言5垡に入っている，中が空っぽの 胡桃の実の様に，徒らに毎日ころがってゆく。働らけど動らけど目に見えて向上しない 自分の境遇に我慢がならなくなる。それに加えて，麦秋の冝下がりなど，これが最後た と言わぬばかりに鳴きしきる蟬時雨が聞こ党，らどうの房のたわわに実り，さんさしの 強い香りが，昼寝の木院にただよう静かな，人気のないこの田舎に生まれた彼の心身 に，民族の遺産とも言うべき，一種の緩みと疲労がつのってきて，自分の将来の生活に す希望が持てない様な気がする。彼は妻にも告げずに家をとび出す。そして, 途で出会 ったのが昔なじみの Segundo とMarcosの二人である。久しぶりに会った彼らの派手 な生活の秘密が, 意外にも，他ならぬ泥棒傢業にあることを知らされて，Don Leiva は䉆く。しかし今は一人息子を失なっていた彼には，むはや，彼らへの仲間入りを妨げ る決定的な要素はない㥞に思えた。しかし; それに踏切るまでの，彼の心の苦しみは， 彼が所詮は根っからのか悪人ではなったことを示している。然し乍ら, 彼らの仕事は残 酷なものだった。主として家畜泥棒だったが，見つけられると，その人を殺し，おまけ に顔の皮まで剝いでしま5ので，市民の恐怖は例えようむなかった。しかし，その手段 の選択は誤っていたが，男の生き甲斐を，スリルに富んだ，男性的な仕事に求めよ 5 と していた Don Leiva は, 彼らとは違って, それ程桁外れに残酷でもなければ, 又臆病 でもなかった。

或る日，或る金持の家を裴 を逃がれて行くえをくらませる。Talca の地ではみんな, 彼は既に死亡したものと思っ ている。それから七，八年経った，そんな或る日彼の昔の友人が，サンチ+ゴ市の街角 で鞓をやっている彼の姿を発見する。そのニュースは，タルカに居た彼の妻に知らさ 
れる。二人の再会の喜びも束の間, 彼は結核にかかって, その動摇に充ちた生涯を閉じ る。

ここで，主人公が遂に，警官に見つからぬままになるストーリーの結末から，我々は 作者の性格と, その意図するものを伺うことが出来る。作者は, 悪そのものへの憎悪よ りも（むしろ，賞めないまでもそれを幾分是認する形とさえなっている）が，主人公の 勇敢さ，男らしさ，人間らしさの強調に主きを拈いている。ここに彼の創作態度の特異 性がある。主人公 Don Leiva がタルカに居たときのこと, 当時, 市民が裁判所の判事 の暴挙に不満をもち，全市民がこれに対して立ち上がった。既に自分は追われる身であ ったが，敢然として彼はその行動に参加し，勇ましく活動した。彼は，このとき流弾に やられ，病院に運ばれるが，脛に傷持つ鹿の悲しさ，充分に治療も受けないまま，こっ そり，そこから抜け出してしまうと言う一幕があった。こんなところにも，主人公の人 間的な一面がしのばれる。

V. El hombre de los ojos azules——自然と人生

アンデス山脈の南端は海に没するあたり,一鈗夫 Pedro el francés の見つけた金 塊のニュースは瞬たく間に，チリーは括ろか遠くヨーロッパ大陸にまで拆がり，Punta Arenas の町は, 各地からやってくる一かく千金を夢みる試掘家たちで, 俄然活気つい てきた。そんな或る日，この町にやってきたのが Kanaka Joe であった。アメリカ生 まれで, なかなかのしたたか者である彼は, Pedro el Prancés と共謀して一儲けしよ 5とする。Pedro は中米のフランス領 Cayena の徒刑場から脱走してきた男たった。

期待された金鉱は遂に見つからず，あれほど賑やかたった町も，次第にさびれていっ た。フェゴ島では, アメリカのドルの威力も, 酷寒の冬の猛威には如何ともすることが 出来なかった、 Kanaka Joe は，おきらめて，Padro と謀って新たに家畜密輸業をは じめる。或る日彼らは別の同業者と道で出会5。Kanaka Jae は彼らが, アルゼンチン の gaucho 上がりの Matías, チリー人の Juan Herrera, 南部土着民の Mariluán の 三人組であることを知る。

二つのグループは互に反目し合う様になる。Pedro と Kanaka Joe は敵方のグルー プを Las Lajas へ追いやってしまう。Las Lajas の町では平和な日が続いた。冝は昼 寝, 夜はバー「ハタゴニアの星」に,一かく千金を夢見る種々雑多な人々が集まる。二 
カ月程経ってからのこと, Juan Herrera は手持ちの金に窮してきた。彼らは Pedro Kanaka Jeo そとのおかげで窮屈な思いをさせられているのだと思 うと，何とかして見返 してやりたい気持ちで一ぱいだった。

Juan : - ¡Gringo cara de caballo alazán!

Mariluán:- Hombre malo, ojos azules.

Mariluán は, 嘗て知り合いの老土人から聞いた金鉱の話を思い出した。彼らはそれ をもって財源としょ5と相談する。老人の言っていた金鉱への正確な道順を知るため, わされさ山を越えて老人に会いにゆく。予定の 1 力月を大部過ぎてから Mariluán は帰 ってきた。彼は, 今は盲人となり, 将に死にかかっていた老人から, 採った金の半分を 面長に渡すと言 万条件で詳しく情報を得， magui の樹液で書いた地図を手にして帰っ てきた。山は，四月頃になると雪が積るので，その頃には，おそくとも帰っていなけれ ばならない。そうすると, あとは二カ月ぐらいしか残っていなかった。彼らは急いで準 備にかかり, 四日間で万事態勢を整えた。食䊓品の大がかりな買込みや，上等な鞍の購 入などは，感の鋭いKanaka や Pedro の注意をひかずにはおらなかった。

出発を数日後にひかえて，Mariluán は，Kanaka と組んでいる居酒屋に招待され， huachacay 酒を领んだ。土人間の習慣として，人に招かれた場合，余程の理由のない 限り,これを拒むことは出来ない。元来酒好きの彼は, 䣲っぱらって, 秘密を洩らして しまった。Juan Herrera と Matías はこれを知ってショックを受けるが，折角の計画 であったので, 男の意地にかけてると出発する。

全く人気のない山道をくねりくねって数日，既に彼等は相当高く登っていた。見下ろ すと; そこにはパタゴニアの平原が広々と，豊かに拡がっていた。それから３日，更に 奥地に入ってゆく。Kanaka Joe らの一行はさとられぬ様に彼らの跡をつけてゆく。 Juan Herrera や Matías が目的地に着き，待望の金を手にして一息ついたとき，銃声 が谷間にこだました。激しい撃ち合いの後, 生き残ったのは Kanaka Joe と Mariluán たけとなった。流石の Kanaka る，余りの残虐さに自から恐れをなし，銃を捨てた。 死人の腰から金の入った袋を契い，更に谷川を溯って金を探しに行った。しかし運命の いたずら，寒波は予想以上に早く到来し，彼の行く手は瞬く間に一面の銀世界となる。 
道を踏み迷った彼にとっては，折角の金も，徒らに自分を疲れさせるのみ。すへての努 カも今は無駄, 彼は, 親友 Pedro に助けられる妄想にとりつかれつつ, 大地の咸とな ってしま5。

以上がこの小説の概略であるが，極めて暗示に富んだストーリーだと言える。この作 品に於ける作者の意図が，はっきりと浮き彫りされていて興味深い。人間のあらゆる照 望, 見にくさ, 争いは, 人間の間ではなかなか解決のつかないものである。しかし, 大 自然の偉大な力は, 我々人力で如何ともし難いものを, 情容赦なく見事に処理してくれ る。そこに又一つの救いの道があると考えている。大自然の裁きは公平であり, 絶対的 である。作者は,どうしても、この主人公 Kanaka Joe を殺したかった。そしてそれ に，象徴的な意味を持たせたかったと考えてよいであろう。ストーリー中に現われる人 物絵巻か，国際的な色彩をもっているところに，そして又, 夫々の人物の果す役割に於 て, 如何にも世界の現状の縮図の様なものを彷彿せしめているところに, この作品の特 徵がある。チリーの南部の僻地に住む人々の生活と, 人間模様が, 国際的なスケールに 於て鮮やかに描き出されている。テーマを特にチリーの南部の, 而も, 或る特定の階層 に限って, これだけ深い観察と, 巧みな描写が出来るのも, やはり彼自身が, 生粋のチ リー人で, その上, 彼らと共にその生活の泉に水を吸んた人であればこそで, 彼独特の こうした作品上の傾向は, 充分に, その存在の価値が認められて然るべであろう。

\section{結 論}

以上見てきた五つの小品を通じて得た結諭として, 次の様に言うことが出来るであろ う。すなわち, 作者は, チリ一の南部の人々の生活と, 彼らの生活を支配している大自 然との相関的な関係を, 特に社会の底辺とも言 らべきところに, 働らく男性を中心とし て, 克明に描き出している。そして, それらの人間に共通した特徴として, 人生に対す

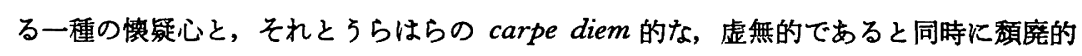
な性格を与えている。それは，作者の作為的な態度によると言うよりも，むしろ，現実 の忠実な描写であると言うべきである。この点に於て, 彼は巧みに, チリー人らしいチ リー人の姿を浮き彫りにしている。たが，この作品は只単なる現実描写の域にとどまる むのではなくて，一つの大きな問題を提起していると同時に，一つの希求をる表わして いるすのたと考えるべきであろう。それこそ，作者の最む大きな目的ではなかったかと 
考える。ところで，彼が特にこうした階層の人々に興味を覚えた理由としては，先にる 述べた，チリー人らしいチリー人を忠実に描きたいと言う意欲もさることながら，それ よりも先ず，彼は自分が育ち，そして生きた世界に，限りない鄉愁と；要着を感してい たからに他ならないだろら。そして, 幼なかりし頃, 又, 長じてからも; 満たされるこ とのなかった大きな希望，個人的なものではなく，国民的な規模に怙けるこうした希望 の，何時かは達成されんことを，この作品に託して，願っている様に思える。登場する 主人公が，どの作品においても，遂には一命を絶つと言了悲劇的な幕切れ，又，それに 関連して，作品全体にたたよう何処となく暗く，もの悲しい空気は，作者の否定的な， 宿命論者的な性格（これは彼の苦悩に満ちた生い立ちに大きく影響されていると考えら れるが）の一局面であり，彼の精神的な大きな特徴である。写実的に，巧みに筋を追っ て淀みのない記述のうまさと，比喻や，寓喻などに富む，而む洗練された文章は，彼が 独学ながら高い教養と，いわゆる文才のある作家であることを証明している。ただ，や

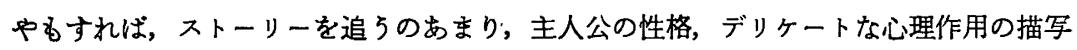
が荒削りになったことと, 主人公と, 彼をめぐる状況との有機的な調和か今一つ望をし いこととが，強いて言えば難点であろう。（大阪外国語大学） 